\title{
FORAGE YIELD AND PERSISTENCE OF RED CLOVER PROGENIES IN TWO ENVIRONMENTS
}

\author{
Daniel Portella Montardo; Miguel Dall’Agnol*; Nilton Rodrigues Paim \\ UFRGS/FA - Depto. de Plantas Forrageiras e Agrometeorologia, C.P. 776 - 91501-970 - Porto Alegre, RS - \\ Brasil. \\ *Corresponding author <migueld@ufrgs.br>
}

\begin{abstract}
Red clover (Trifolium pratense L.) is one of the most important temperate legume species, used to lessen the lack of forage during the critical fall-winter period in Rio Grande do Sul, RS, Brazil. However, its utilization has been restricted mainly because of its lack of persistence. This work evaluates the dry matter yield and persistence of red clover half-sib progenies in two physiographic regions of RS: "Depressão Central", in Eldorado do Sul and "Encosta Superior do Nordeste", in Veranópolis. Experiments were carried out for two growing seasons and results were compared to two red clover commercial checks, Qüiñequeli and Estanzuela 116. The region of Veranópolis was more adequate for red clover forage production, enabling better yield and persistence. The best check for both locations was cultivar Estanzuela 116. At Eldorado do Sul persistence was highly affected and some progenies were superior to the best check. At Veranópolis the best check was very productive, with good persistence. The best progenies at both locations were selected to be propagated and submitted to additional recurrent selection cycles.
\end{abstract}

Key words: environment, genotype, plant breeding

\section{PRODUÇÃO DE FORRAGEM E PERSISTÊNCIA DE PROGÊNIES DE TREVO VERMELHO EM DOIS AMBIENTES}

\begin{abstract}
RESUMO: O trevo vermelho (Trifolium pratense L.) é uma das mais importantes leguminosas temperadas e é utilizado para minorar o problema de falta de forragem durante o período crítico do outono no Rio Grande do Sul. Entretanto seu uso tem sido limitado devido principalmente à sua falta de persistência. O presente trabalho teve por objetivo avaliar a persistência e a produção de matéria seca de progênies de meio-irmãos de trevo vermelho em duas regiões fisiográficas do RS: Depressão Central, em Eldorado do Sul, e Encosta Superior do Nordeste, em Veranópolis. O experimento foi conduzido por duas estações de crescimento e os resultados foram comparados com os de dois cultivares comerciais de trevo vermelho, Qüiñequeli e Estanzuela 116, utilizados como padrões. A região de Veranópolis mostrou-se mais indicada para o cultivo de trevo vermelho do que a região de Eldorado do Sul, proporcionando maior produção e persistência. Nos dois locais o melhor padrão foi o cultivar Estanzuela 116. Em Eldorado do Sul a persistência foi muito afetada e algumas progênies foram superiores ao melhor padrão. Por outro lado, em Veranópolis o melhor cultivar-padrão foi muito persistente e produtivo. Em ambos os locais foram selecionadas as melhores progênies para multiplicação e realização de novos ciclos de seleção recorrente.

Palavras-chave: ambiente, genótipo, melhoramento genético
\end{abstract}

\section{INTRODUCTION}

Red clover is a cross-pollinated legume that gives good, high-quality forage yield in many regions of Rio Grande do Sul, Brazil (Araújo, 1967; Moojen, 1979; Jacques et al., 1995; Oliveira \& Moraes, 1995). Since part of the production is concentrated around the cold season, it becomes an alternative crop for cattle feeding during that period, when natural pastures usually present little growth and low quality.

Basically three red clover cultivars are utilized in Rio Grande do Sul: Kenland, of North-American origin; Qüiñiqueli, from Chile; and Estanzuela 116, from Uruguay (Paim, 1988). In spite of being well adapted to the local edaphic-climatic conditions, these cultivars present a few problems. Main drawback is their low persistence. Despite being perennial species, it usually behaves as annual or biennial plants, and this reduces its productive potential in the long run. In addition, most red clover seeds are imported, and their price is thus linked to exchange rate variations, leading to considerable reduction of the planted area when seed prices are high.

The objective of this work was testing and selecting half-sibling progenies from plants presenting superior traits, in two different locations, emphasizing persistence and forage yield. This work is part of a red clover breeding program aimed at developing germplasm that would be more adequate for the region's edaphic-climatic 
conditions, an attempt to make red clover a viable feeding alternative for cattle in Rio Grande do Sul during the cold season, either as single cropping intercropped with cultivated forage grasses, or as a species grown to improve native pastures.

\section{MATERIAL AND METHODS}

Forty eight out of 300 plants previously evaluated (Crusius, 1997) - seed and dry matter yield, height and diameter growth rates, and regrowth potential - were compared to two commercial cultivars, Qüiñiqueli and Estanzuela 116 taken as standards, comprising 50 treatments distributed in a randomized block design $(n=4)$. Each plot consisted of a two-meter-long row, the central meter considered for evaluations.

The experiment was installed in: Eldorado do Sul, $\mathrm{RS}$, at the "Depressão Central" region $\left(30^{\circ} 05^{\prime} 02\right.$ "S, $51^{\circ} 36^{\prime} 58^{\prime \prime} \mathrm{W}, 40 \mathrm{~m}$ altitude), on 14 June, 1996; and, Veranópolis, RS, at the "Encosta Superior do Nordeste" region $\left(28^{\circ} 56^{\prime} 10^{\prime \prime} \mathrm{S}, 51^{\circ} 32^{\prime} 58^{\prime \prime} \mathrm{W}, 705 \mathrm{~m}\right.$ altitude), on 12 July, 1996. Soil at Eldorado do Sul is a Plinthosol, and at Veranópolis is a Reddish Brunizem. In both locations the soil was previously fertilized and corrected according to the results of soil analysis (Recomendações, 1995).

Dry matter yield was evaluated by cuts at 8 to 10 $\mathrm{cm}$ every time plants reached 30 to $40 \mathrm{~cm}$; data were presented as grams of dry matter per linear meter. Two growing cycles of the forage species (1996/97 and 1997/98) were evaluated for both locations.

Four cuts were performed during the experimental period at Eldorado do Sul, two in the first growing cycle and two in the second. Cuts were done on 11/07/96, 12/ $12 / 96,10 / 21 / 97$ and 01/08/98. Seven cuts were performed during the experimental period at Veranópolis, three in the first growing cycle (1996/97) and four in the second (1997/ 98); 11/19/96, 01/08/97, 03/10/97, 04/29/97, 09/16/97, $12 /$ $01 / 97$ and 01/28/98. Because red clover is a perennial, temperate climate species, the beginning of the second growing cycle was considered as fall 1997, i.e., from the fourth cut on (04/29/97). Persistence was evaluated visually (scale from zero to five), and the highest value was attributed to the most persistent progenies. Ratings were attributed according to stand and vigor of the plants, in each experimental plot, at the end of the period.

Data were analyzed using the SAS (Statistical Analysis Systems, 1994) software. Total dry matter yield was initially analyzed for each location and a joint analysis of the experiments was performed to verify the occurrence of genotype $\times$ environment interaction.

Since the variable dry matter yield required observations in time, it was analyzed according to the Longitudinal Data Analysis Methodology (Castro, 1997); the Analysis of Variance for Repeated Measures was utilized, through the PROC GLM SAS (Statistical Analysis Sys- tems, 1994) procedure. However, the variable persistence, resulting from a single observation per experimental unit, was statistically analyzed by the F test (Anova). The comparison between treatment means utilized individual contrasts for each variable, between the best progenies in each variable and the best standard cultivar.

\section{RESULTS AND DISCUSSION}

When interaction genotype $\times$ environment was observed, two different selection strategies could be pursued. At first, the selection of genotypes that have greater production stability and adaptability to the environment, even not being the most productive and persistent in each location individually. In this type of breeding work, interest lies in genotypes with good capacity of adaptation to the different environments, where good average behavior is acceptable, enabling them to be recommended to broader regions. On another instance, it is possible to invest in the specific capacity of adaptation of certain genotypes to certain environments, selecting those presenting the best behavior in each environment. In this case, selected cultivars or varieties should be recommended for environments similar to those where selection was performed, turning the breeding project an effort directed to specific regions.

The joint analysis of the experiments for variable total dry matter was significant $(P<0.001)$ for the genotype $\times$ environment interaction, indicating that the behavior of progenies varied depending on the environments, which quite distinct climatic traits (Table 1). Since the genotype $\times$ environment interaction was significant for total dry matter yield, the statistical analysis for each cut considered the locations separately, once the decision was made to select plants for each environmental condition.

At Eldorado do Sul, none of the best ten progenies was different from the best standard [cultivar (cv.) Estanzuela 116] for the first cut (Table 2). However, progenies 4-36 and 3-37 were more productive than the standard at the second cut.

For the third cut, once again individual contrasts did not indicate any progenies more productive than cv. Estanzuela 116, while yields from progenies 5-25 $(P<0.01), 6-46(P<0.05)$, and progenies $3-24,3-37$ and $1-41(P<0.10)$ for the fourth cut were superior $(P<0.01)$ to the standard. Some progenies had similar yields at the third and fourth cuts, while cv. Estanzuela 116, at the last cut, reduced its mean dry matter yield to approximately one third of that obtained in the previous evaluation, providing evidence of a shorter yield longevity. After the fourth cut, no plot recovered to an extent that would allow new dry matter evaluations and, on March 3, 1998, the field work in Eldorado do Sul was discontinued since all plants died. 
Table 1 - Mean global incident radiation, mean temperature, mean maximum temperatures and mean monthly rainfall at Eldorado do Sul and Veranópolis.

\begin{tabular}{lcccccccc}
\hline \multirow{2}{*}{ Month } & \multicolumn{2}{c}{ Radiation } & \multicolumn{2}{c}{ Mean Temp. } & \multicolumn{2}{c}{ Max. Temp. } & \multicolumn{2}{c}{ Rainfall } \\
\cline { 2 - 7 } & Eld. $^{1}$ & Ver. $^{2}$ & Eld. & Ver. & Eld. & Ver. & Eld. & Ver. \\
\hline Jan & 489 & 590 & 24.8 & 22.0 & 30.0 & 26.1 & 114.8 \\
Feb & 443 & 532 & 24.9 & 21.7 & 30.0 & 26.3 & 107.6 & 121.7 \\
Mar & 386 & 468 & 23.4 & 20.3 & 28.7 & 24.8 & 106.7 & 134.5 \\
Apr & 332 & 366 & 19.8 & 17.3 & 24.9 & 21.9 & 101.8 & 93.9 \\
May & 242 & 326 & 16.1 & 15.0 & 21.4 & 19.6 & 115.7 & 84.4 \\
Jun & 206 & 271 & 13.9 & 13.1 & 18.4 & 17.4 & 168.2 & 137.5 \\
Jul & 213 & 295 & 14.2 & 13.4 & 19.0 & 17.9 & 145.0 & 115.7 \\
Aug & 248 & 308 & 15.0 & 13.7 & 19.4 & 18.4 & 145.3 & 183.8 \\
Sep & 322 & 381 & 17.0 & 15.6 & 21.4 & 20.1 & 128.2 & 181.1 \\
Oct & 414 & 496 & 18.9 & 17.4 & 23.9 & 22.0 & 103.4 & 146.7 \\
Nov & 475 & 567 & 21.0 & 19.5 & 26.3 & 24.3 & 107.9 & 126.5 \\
Dec & 509 & 606 & 23.4 & 21.2 & 28.7 & 26.1 & 95.7 & 155.9 \\
\hline
\end{tabular}

Source: Adapted from Bergamaschi \& Guadagnin (1990) and IPAGRO (1979).

${ }^{1}$ Eldorado do Sul. ${ }^{2}$ Veranópolis

Table 2 - Means for dry matter yield, per cut and total, of the ten most productive progenies, mean of $\mathrm{cv}$. Estanzuela 116 and overall mean for all treatments at Eldorado do Sul.

\begin{tabular}{|c|c|c|c|c|c|}
\hline \multirow{2}{*}{$\begin{array}{l}\text { Progeny/ } \\
\text { Cultivar }\end{array}$} & \multicolumn{2}{|c|}{$\begin{array}{l}\text { First cycle } \\
(1996 / 97)\end{array}$} & \multicolumn{2}{|c|}{$\begin{array}{c}\text { Second cycle } \\
(1997 / 98)\end{array}$} & \multirow[t]{2}{*}{ Total } \\
\hline & Cut 1 & Cut 2 & Cut 3 & Cut 4 & \\
\hline & \multicolumn{5}{|c|}{ - g DM per liner $m$ - } \\
\hline $3-24$ & 269 & 120 & 213 & $132^{+}$ & $734^{+}$ \\
\hline $6-46$ & 217 & 124 & 151 & $150 *$ & 642 \\
\hline $4-36$ & 213 & $189 * *$ & 118 & 113 & 633 \\
\hline $5-25$ & 194 & 105 & 121 & $211 * *$ & 631 \\
\hline $6-33$ & 255 & 109 & 163 & 97 & 624 \\
\hline $6-2$ & 332 & 83 & 131 & 48 & 594 \\
\hline $4-31$ & 301 & 102 & 133 & 40 & 576 \\
\hline $2-23$ & 248 & 117 & 102 & 93 & 560 \\
\hline $3-37$ & 199 & $144 *$ & 90 & $126^{+}$ & 559 \\
\hline $1-41$ & 189 & 123 & 119 & $124^{+}$ & 555 \\
\hline Estanzuela & 194 & 99 & 144 & 46 & 483 \\
\hline Mean $^{1}$ & 230 & 110 & 54 & 41 & 435 \\
\hline $\mathrm{CV}(\%)$ & 38.09 & 27.33 & 160.40 & 159.69 & 44.80 \\
\hline
\end{tabular}

Means followed by ${ }^{+}, *$ and $* *$ are significantly different from $\mathrm{cv}$. Estanzuela 116, at the 10,5 and $1 \%$ levels, respectively, by $F$ test for individual contrasts.

${ }^{1}$ Mean of 50 treatments (48 progenies and 2 controls).

With reference to total dry matter yield in Eldorado do Sul, only progeny 3-24 presented higher yield $(P<0.10)$ than $\mathrm{cv}$. Estanzuela 116 . This cultivar was only ten percent superior to the general mean for the experiment, indicating a lack of commercial cultivars adapted to the Eldorado do Sul region.
The coefficients of variation were compatible with the expected for the first two cuts (first production cycle), since even in half-sibling progenies there is much variation between individuals, within progenies in allogamous species, as in the case of red clover (Table 2). The coefficients of variation determined in the third and fourth cuts (second growing cycle) were higher than in the first growing cycle. However, this is justified by the fact that many reductions in plant stand occurred by the end of the first production cycle, resulting in a great range of variation between replicates. In many plots, all plants died, and since one of the objectives was to test dry matter yield as a function of persistence, "zero" was attributed to dry matter yield of those plots, resulting in high coefficients of variation. At Veranópolis, there were differences between some of the best progenies and the best standard cultivar (cv. Estanzuela 116) for almost all cuts, as well as for total dry matter yield (Table 3).

In the first cut, progenies 2-7, 3-20 and 3-32 were more productive than cv. Estanzuela 116. These were quite early in terms of forage yield and remained productive through the entire first growing cycle.

No differences occurred in the second and fourth cuts with respect to dry matter yield between the best progenies and cv. Estanzuela 116. In the fourth cut (04/ 29/97), all treatments presented reduced dry matter yield. In addition to the water deficit that occurred during March and most of April, 1997, this can also be explained by the fact that the plants were between the end of the first growing cycle and the beginning of the second. However, this production was very important, since it occurred during a critical season (fall), when the sum- 
Table 3 - Means for dry matter yield, per cut and total of the nine most productive progenies, mean of cv. Estanzuela 116 (used as comparative control) and overall mean for all treatments in Veranópolis.

\begin{tabular}{|c|c|c|c|c|c|c|c|c|}
\hline \multirow[t]{2}{*}{$\begin{array}{l}\text { Progeny/ } \\
\text { cultivar }\end{array}$} & \multicolumn{3}{|c|}{ First cycle $(1996 / 97)$} & \multicolumn{4}{|c|}{ Second cycle (1997/98) } & \multirow[b]{2}{*}{ Total } \\
\hline & cut $1 *$ & cut 2 & cut 3 & cut 4 & cut 5 & cut 6 & cut 7 & \\
\hline & 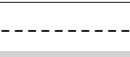 & 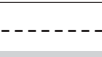 & . & g DM & ear $\mathrm{m}$ - & - n & - & 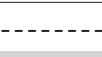 \\
\hline $2-7$ & $405 * *$ & 252 & 199 & 48 & 218 & $276^{+}$ & $73 * *$ & 1471 \\
\hline $5-40$ & 260 & 272 & $250 *$ & 46 & 182 & 293 & $63 * *$ & 1366 \\
\hline $3-20$ & $349+$ & 242 & 194 & 60 & $167^{+}$ & $267 *$ & $60 * *$ & 1339 \\
\hline $6-31$ & 310 & 268 & $235^{+}$ & 47 & 169 & $223 * *$ & $79 * *$ & 1331 \\
\hline $2-23$ & 274 & 253 & $244 *$ & 47 & 174 & 283 & $46 * *$ & 1321 \\
\hline $3-25$ & 296 & 246 & 192 & 45 & $158 *$ & 284 & $98 *$ & 1319 \\
\hline $3-32$ & $369 *$ & 258 & 228 & 57 & $162^{+}$ & $204 * *$ & $38 * *$ & 1316 \\
\hline $3-35$ & 272 & 236 & 207 & 42 & 191 & $256^{*}$ & $86 * *$ & $1290^{+}$ \\
\hline $2-34$ & 298 & 224 & 174 & 45 & $149 *$ & $271 *$ & $84 * *$ & $1245^{+}$ \\
\hline Estanzuela & 284 & 225 & 189 & 49 & 208 & 341 & 137 & 1433 \\
\hline Mean $^{1}$ & 262 & 240 & 203 & 43 & 142 & 227 & 68 & 1185 \\
\hline $\mathrm{CV}(\%)$ & 19.70 & 18.26 & 18.08 & 35.86 & 23.76 & 22.66 & 31.84 & 10.24 \\
\hline
\end{tabular}

Means followed by ${ }^{+}$, *and **are significantly different from cv. Estanzuela 116, at the 10, 5 and $1 \%$ levels, respectively, by $\mathrm{F}$ test for individual contrasts.

${ }^{1}$ Mean of 50 treatments (48 progenies and 2 controls).

mer pastures had almost finished their cycles and the annual winter pastures had not yet begun their productive periods.

For the third cut, progenies 5-40, 6-31 and 2-23 were superior to cv. Estanzuela 116 with regard to dry matter yield, and the ability of these genotypes to extend their productive period practically until the end of summer (March 10) in Veranópolis became evident. From the fifth cut forth, cv. Estanzuela 116 started to become prominent among the other treatments, showing good adaptation to this region. For this cut progenies 3-20, 3-25, 3-32 and 2-34 were below the standard.

In the sixth cut, only progenies 5-40, 2-23 and 3-25 were not less productive than cv. Estanzuela 116, while for the seventh cut, this cultivar was superior to all treatments. Despite the fact that yields of the seventh cut were not high, greater differences in favor of cv. Estanzuela 116 occurred for this cut, which emphasizes its productive longevity in this environment. The standard cultivar was the second-best treatment in total dry matter yield, superior to progenies 3-35 and 2-34.

With regard to total dry matter yield obtained in two consecutive cycles, several progenies showed productive potential similar to cultivar Estanzuela 116, providing evidence of the success of the ongoing breeding program.

When the two locations are compared in terms of dry matter yield (Figure 1), attention is first drawn to the fact that in Eldorado do Sul plants better yields concentrated around winter and spring, both in the first and the second growing cycles. Apparently the high temperatures recorded in summer, in association to water deficit periods, did not allow plants to produce forage for a longer period.

At Veranópolis the red clover plants extended their productive period until the beginning of fall in the first cycle. In the second cycle, because of the fact that plants are perennial and already established, their production was anticipated, with $39 \%$ of the total yield occurring before the beginning of spring. The second production cycle at Veranópolis was evaluated only at the end of January, 1998, and it is possible that some progenies would grow further. In both locations the best standard in terms of forage yield was cv. Estanzuela 116, contrasting with cv. Qüiñequeli, for Eldorado do Sul and Veranópolis (data not presented).

Red clover is better adapted to Veranópolis (Figure 2), where temperatures in summer are milder and rainfall is better distributed throughout the year (Table 1), as also observed by Araújo (1967). The total forage yield obtained in this location by the end of both growing cycles (means of all treatments) was higher $(P<0.0001)$ than in Eldorado do Sul, where many progenies were subject to stand reduction, or even disappeared completely by the end of the first production cycle.

Since plants were grown in rows spaced at $1 \mathrm{~m}$, it was not possible to estimate yields accurately as $\mathrm{kg} \mathrm{DM} \mathrm{ha}{ }^{-1}$. However, considering that the row spacing utilized in the pasture in $1 \mathrm{~m}$, which is much wider than usual, it was possible to estimate yield per ha in both locations, for comparison purposes, without running the risk of overestimation. Therefore, the mean red clover yield 

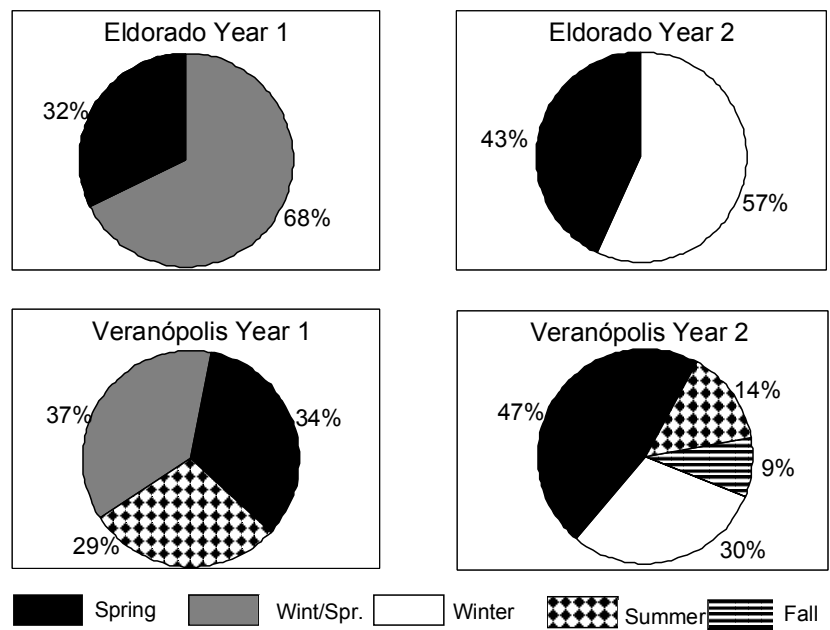

Figure 1- Seasonal distribution of dry matter yield in Eldorado do Sul and Veranópolis during the two years of evaluation, considering the winter, winter-spring, spring, summer and fall periods.

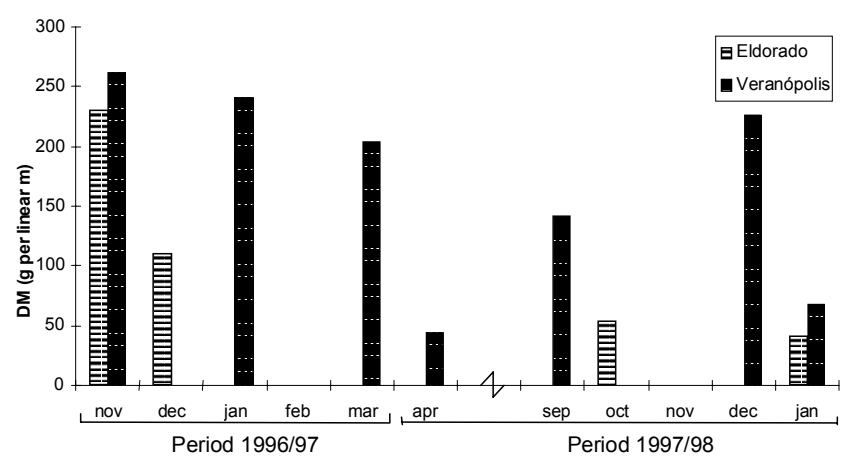

Figure 2 - Dry matter yield per cut (mean of all treatments) for Eldorado do Sul and Veranópolis.

Table 4 - Evaluation of persistence by visual ratings (0 - 5) of the best ten progenies and of cultivar Estanzuela 116 in Eldorado do Sul and Veranópolis.

\begin{tabular}{|c|c|c|c|}
\hline \multicolumn{2}{|c|}{ Eldorado do Sul } & \multicolumn{2}{|c|}{ Veranópolis } \\
\hline Treatment & Persistence & Treatment & Persistence \\
\hline $5-25$ & $4.25 * *$ & $1-45$ & 4.50 \\
\hline $2-24$ & $3.25^{*}$ & $5-25$ & 4.50 \\
\hline $1-41$ & $3.00^{+}$ & $2-24$ & 4.25 \\
\hline $3-24$ & $3.00^{+}$ & $3-25$ & 4.25 \\
\hline 4-36 & $3.00^{+}$ & $3-37$ & 4.25 \\
\hline $3-37$ & 2.75 & $4-22$ & 4.25 \\
\hline $6-33$ & 2.75 & $6-46$ & 4.00 \\
\hline $6-46$ & 2.75 & $2-7$ & 4.00 \\
\hline $2-23$ & 2.25 & $3-35$ & 4.00 \\
\hline $5-19$ & 2.00 & $5-45$ & 4.00 \\
\hline Estanzuela 116 & 2.00 & Estanzuela 116 & 4.25 \\
\hline CV (\%) & 111.8 & CV (\%) & 28.5 \\
\hline
\end{tabular}

Means followed by ${ }^{+},{ }^{*}$ and ${ }^{* *}$ are significantly different from $\mathrm{cv}$. Estanzuela 116, at the 10,5 and 1\% levels, respectively, by $\mathrm{F}$ test for individual contrasts. in the first growing cycle at Eldorado do Sul was $3,407 \mathrm{~kg} \mathrm{DM} \mathrm{ha}^{-1}$, while at Veranópolis 7,490 $\mathrm{kg} \mathrm{DM} \mathrm{ha}^{-1}$, reinforcing the best yield potential of the species at the latter location.

With regard to the progeny with highest total dry matter yield in Veranópolis (progeny 2-7), its estimated yield in the first growing cycle was $9,040 \mathrm{~kg} \mathrm{DM} \mathrm{ha}^{-1}$. Saibro (1972) compared several red clover cultivars in Vacaria, a region similar to Veranópolis, and obtained the highest dry matter yield in the first year with the cultivar Chesapeake $\left(7,897 \mathrm{~kg} \mathrm{DM} \mathrm{ha}{ }^{-1}\right)$. Macedo et al. (1976) evaluated the response of a pasture composed of fescue (Festuca arundinacea) and red clover to liming and phosphorus sources in Lagoa Vermelha, another region similar to Veranópolis, and obtained for the best treatment, in three cuts, 2,869 $\mathrm{kg} \mathrm{DM} \mathrm{ha}^{-1}$ of red clover, a total of $5,353 \mathrm{~kg} \mathrm{DM} \mathrm{ha}^{-1}$ in the mixture.

Final persistence at Eldorado do Sul was evaluated on 18 December, 1997. There were differences between treatments, with progenies 5-25, 2-24, 1-41, 3-24 and 4-36 persisting better than cv. Estanzuela 116 (Table 4), which also was the best standard with regard to this variable. At Veranópolis, persistence was evaluated on 18 March, 1998, and despite the differences between treatments, none of the best 10 progenies was different from the best standard, cv. Estanzuela 116 (Table 4).

Similar to what occurred with dry matter yield in Eldorado do Sul for the second growing cycle, persistence evaluation at this location had a high coefficient of variation, probably because intrinsic variability observed in half-sib progenies of allogamous species (which is the case in red clover) and great mortality, occurring by chance, among plants of the same progeny, affecting the homogeneity of replicates in the experiment. At Veranópolis there was greater plot uniformity (less mortality) and, as a consequence, coefficients of variation were always acceptable. Low persistence in this species was due to the stress caused by short dry spells and high temperatures in Kentucky and Mississippi (USA) Matches (1989). Temperatures above $30^{\circ} \mathrm{C}$ are highly detrimental to persistence in temperate legumes, while $35^{\circ} \mathrm{C}$ is critical for the majority of those species (Paim, 1988).

Kendall (1958), using cloned red clover plants, also showed concern with respect to red cloves being cultivated under high temperatures. That author evaluated plant development under several day and night temperatures, and concluded that the optimal temperatures for production and persistence of red clover are $24^{\circ} \mathrm{C}$ during the day and $18^{\circ} \mathrm{C}$ during the night. Climatic differences between the two regions, especially in terms of temperature, determined the greater persistence of progenies at Veranópolis, allowing one extra cut to be made in the fall, despite the low accumulation of dry matter (Table 3 and Figure 2). The two standard cultivars did not differ in persistence (data not shown); among the 10 most persistent 
progenies in Eldorado do Sul, four (5-25, 2-24, 3-37, 646) are also among the 10 most persistent at Veranópolis, indicating that they adapt well to both regions. With respect to dry matter yield, only one progeny (2-23) was among the best ten in both regions.

Considering the extents of environmental differences between the two regions, as well as responses of progenies at each location, selections in each environment were performed disregarding progenies individually, but considering performance in each region instead. In Eldorado do Sul, some progenies performed better than the best standard cultivar, in terms of dry matter yield and persistence, and were selected for evaluation in subsequent phases of the breeding program. Allthough no progeny was positively and significantly differentiated from the best standard in relation to dry matter yield and persistence at Veranópolis, this stage of the breeding program was worthwhile at that location, because of the excellent mean productive potential shown by progenies tested. Selected progenies should be monitored constantly, however, through future generations, so that desirable traits can be maintained.

\section{ACKNOWLEDGEMENT}

The corresponding author would like to thank $\mathrm{CNPq}$ for the fellowship.

\section{REFERENCES}

ARAÚJO, A.A. Forrageiras para ceifa. Porto Alegre: Sulina, 1967. 154p. BERGAMASCHI, H.; GUADAGNIN, M. Agroclima da Estação Experimental Agronômica da UFRGS. Porto Alegre: UFRGS, 1990. 98p.

CASTRO, S.M. de J. A metodologia de análise de dados longitudinais. Porto Alegre: UFRGS/Instituto de Matemática, Depto. de Estatística, 1997. 114p. (Monografia -Bacharel)
CRUSIUS, A.F. Avaliação da variabilidade de características agronômicas de uma população de Trifolium pratense L. Porto Alegre: UFRGS, 1997. 98p. (Dissertação -Mestrado)

INSTITUTO DE PESQUISAS AGRONÔMICAS - IPAGRO. Observações meteorológicas no Estado do Rio Grande do Sul. Porto Alegre: IPAGRO; Secretaria da Agricultura, 1979. (Boletim Técnico, 3).

JACQUES, A.V.A.; SAIBRO, J.C.; LOBATO, J.F. et al. Sistema de produção de forragem para Depressão Central/RS. In: FEDERACITE. Cadeias forrageiras regionais. Porto Alegre: Caramuru, 1995. p.13-28.

KENDALL, W.A. The persistence of red clover and carbohydrate concentration in the roots at various temperatures. Agronomy Journal, v.50, p.657-659, 1958.

MACEDO, W.; JACQUES, A.V.A.; STAMMEL, J.G. Resposta de misturas forrageiras à aplicação de calcário e de diferentes fontes de fósforo em dois tipos de solos do Rio Grande do Sul. Pesquisa Agropecuária Brasileira, v.11, p.33-40, 1976

MATCHES, A.G. A survey of legume production and persistence in the United States. In: MARTIN, G.C. (Ed.) Persistence of forage legumes. Madison: ASA, 1989. p.37-43.

MOOJEN, E.L. Rendimento e qualidade de misturas forrageiras de estação fria submetidas a dois regimes de corte. Porto Alegre: UFRGS, 1979. 124p. (Dissertação - Mestrado)

OLIVEIRA, J.C.P.; MORAES, C.O.C. Cadeia forrageira para a região da Campanha. In: FEDERACITE. Cadeias forrageiras regionais. Porto Alegre: Caramuru, 1995. p.29-42.

PAIM, N.R. Manejo de leguminosas de clima temperado. In: SIMPÓSIO SOBRE MANEJO DE PASTAGEM, 9., Piracicaba, 1988. Anais. Piracicaba: FEALQ, 1988. p.341-358.

RECOMENDAÇÕES de adubação e de calagem para os estados do Rio Grande do Sul e Santa Catarina. 3.ed. Passo Fundo: SBCS, Núcleo Regional Sul, 1995. 224p.

SAIBRO, J.C. de. Competição entre variedades de espécies de gramíneas e leguminosas forrageiras anuais e perenes de estação fria. In: UNIVERSIDADE FEDERAL DO RIO GRANDE DO SUL. Faculdade de Agronomia. Relatório de Pesquisa Período 1965-1972. Porto Alegre: Faculdade de Agronomia, Setor de Plantas Forrageiras. 1972. p.68-71. SAS INSTITUTE. User's guide: version 6. 4.ed. Cary: Statistical Analysis System Institute, 1994. v.2.

Received September 12, 2001

Accepted May 13, 2003 